\title{
Internal bioerosion of Acropora formosa in Réunion (Indian Ocean): microborer and macroborer activities
}

\author{
Mayalen ZUBIA, Mireille PEYROT-CLAUSADE* \\ UMR CNRS 6540, Centre d'océanologie de Marseille, Université de la Méditerranée, \\ rue de la Batterie-des-Lions, 13007 Marseille, France
}

Received 16 October 2000; revised 16 January 2001; accepted 17 January 2001

\begin{abstract}
Bioerosion by grazing and boring organisms is one of the major destructive forces operating on reef. The aim of this study was to estimate the intensity of internal bioerosion by both microflora and fauna of Acropora, a branching scleractinian, on the reef flat at La Saline (Réunion, Indian Ocean). Internal bioerosion was estimated at two sites, varying in degrees of eutrophication. At each site, dead Acropora subjected to heavy grazing or covered by algal turf were examined. Acropora formosa is subjected to high bioerosion due to its high porosity and its branching form, which facilitates colonisation by boring organisms. Three endolithic microflora species, Plectonema terebrans, Mastigocoleus testarum and Ostreobium queckettii colonised the branches. The mean density of polychaetes was high (72 individuals $\mathrm{cm}^{-3}$ ), and all were regarded as meiofauna (diameter $<0.5 \mathrm{~mm}$ ). The main agents of bioerosion of Acropora formosa were boring microflora whose boring activities were four times greater $\left(0.29 \mathrm{~g} \mathrm{~cm}^{-3}\right.$ of $\left.\mathrm{CaCO}_{3}\right)$ than that recorded by the boring fauna $\left(0.07 \mathrm{~g} \mathrm{~cm}^{-3}\right.$ of $\left.\mathrm{CaCO}_{3}\right)$. Under high levels of eutrophication, the microflora were responsible for high bioerosion (30.8\% of the surface of the substrate). In contrast, the composition of the fauna changed under these conditions but not the rate of bioerosion (4.4\% maximum of the volume of dead Acropora). At the undisturbed site, the substrate covered by algae (within damselfish territory and therefore not subjected to grazing) had low levels of bioerosion caused by microflora ( $18.9 \%$ of the surface) and high bioerosion by fauna ( $9.5 \%$ maximum of the volume of dead Acropora) and in addition the composition of boring fauna was different to that found at the disturbed site with sipunculans being the dominant agent of bioerosion (6 individuals $\mathrm{cm}^{-3}$ maximum). (C) 2001 Ifremer/CNRS/IRD/Éditions scientifiques et médicales Elsevier SAS
\end{abstract}

Résumé - Bioérosion interne d'Acropora formosa (île de la Réunion, océan Indien) : activité des micro- et des macro-organismes perforants. La bioérosion par les organismes brouteurs et perforants est un processus majeur dans la destruction des récifs coralliens. Le but de cette étude est d'estimer l'intensité de la bioérosion interne d'Acropora formosa par la microflore et la microfaune sur le récif de La Saline. La bioérosion interne est étudiée sur deux sites en fonction du degré d'eutrophisation et du type de recouvrement du substrat (brouté ou recouvert d'un gazon algal). La bioérosion d'A. formosa est très élevée en raison de sa très forte porosité et de sa forme branchue, qui augmente la surface disponible à la colonisation par les perforants. Plectonema terebrans, Mastigocoleus testarum et Ostreobium queckettii sont les trois espèces principales de la microflore endolithique qui colonisent ces branches. Les polychètes, dont la densité moyenne est élevée $\left(72\right.$ individus $\left.\mathrm{cm}^{-3}\right)$, appartiennent à la meiofaune (diamètre $<0,5 \mathrm{~mm}$ ). La bioérosion résulte principalement de l'activité de la microflore $\left(0,29 \mathrm{~g} \mathrm{~cm}^{-3} \mathrm{de} \mathrm{CaCO}_{3}\right)$ qui est 4 fois supérieure à celle de la meiofaune $\left(0,07 \mathrm{~g} \mathrm{~cm}^{-3}\right.$ de $\left.\mathrm{CaCO}_{3}\right)$. En milieu eutrophisé, 30,8\% de la surface du squelette est perforée par la microflore et $4,4 \%$ du volume érodé par la meiofaune. En milieu témoin, le plus faible pourcentage de bioérosion

*Correspondence and reprints: fax: +33491041635.

E-mail address: peyrot@com.univ-mrs.fr (M. PEYROT-CLAUSADE).

(C) 2001 Ifremer/CNRS/IRD/Éditions scientifiques et médicales Elsevier SAS. Tous droits réservés 
$(18,9 \%)$ par la microflore est relevé dans les substrats couverts de feutrage algal alors que la bioérosion par la faune atteint $9,5 \%$ du volume du squelette due principalement à l'activité des siponcles (6 individus $\mathrm{cm}^{-3}$ ). (C) 2001 Ifremer/CNRS/IRD/Éditions scientifiques et médicales Elsevier SAS

\section{Acropora / bioerosion / boring organisms / coral reef / Indian Ocean}

\section{Acropora / bioérosion / organismes perforants / récifs coralliens / océan Indien}

\section{INTRODUCTION}

Bioerosion is one of the important factors affecting the maintenance and persistence of coral reefs Hubbard ed al 1990. Rates of bioerosion may vary in space and time Chazottes et al. 1995: Kiene and Hutchings, 1994h: Par Et al, 1998; Conand et al, 1998) They are influenced by a number of biotic and abiotic factors (Risk et_al. 1995) and more particularly by eutrophication, which has been shown to promote bioerosion intensity Hallock, 1988. Eari, 1998:Helmes et al, 2000) The structure of the boring community is also related to the skeletal density Highsmith, 1981 and the internal structure of the coral CAmor et al. 1991).

In a previous study, Peyrot-Clamsade_et_al_(1999) suggested that the difference in the rates of bioerosion between La Saline reef (Réunion) and Tiahura reef (Moorea, French Polynesia) were due to differences in dominant coral species. Porites sp. constituted $94.2 \%$ of the living coral coverage on Tiahura and Acropora sp. $49 \%$ on Trou d' Eau reef flat. On the Great Barrier Reef, Risk et al.(1995) estimated that boring in Acropora formosa was two to three times higher than found in Porites lobata, which tended to support the hypothesis of Peyrot-Clausade et al. (1999).

Although bioerosion in Porites, a massive scleractinian, by microborers Le Campion-Alsumard et al. 1995) and macroborers Hutchings et al. 1992: Peyrot-Clausade ed 6l, 1992) has been well studied, there are only a few studies on Acropora (Musso, 1994, Risk et al.,1995) and on branching coral rubble (Holmes et al, 2000) and none regarding microborers.

The aim of this work was to study bioerosion in Acropora, a branched coral, on La Saline reefs (Réunion) at two sites. One site was exposed to nutrient-rich groundwater impact and the second site was undisturbed Cuet et al. 1988, Conand et al. 1998) Grazing is also known to have significant effects on internal bioerosion of dead corals (Sammarco et al., 1987) The damselfish,
Stegastes nigricans, actively exclude other herbivores from their territories, and thereby create under-grazed patches in the environment. The relative abundance of bioeroding organisms and their boring activities within the tips of branches of dead Acropora formosa under variable grazing conditions and at disturbed and undisturbed sites.

\section{MATERIALS AND METHODS}

\subsection{Study area}

In October 1998, samples of Acropora formosa were collected from two sites of La Saline reef (Réunion, Indian Ocean) on the reef flat (fgure $)$ : Trou d' Eau site which is an undisturbed site and where Acropora formosa constitute $12.3 \%$ of the coverage Peyrot-Clausade et al. 1999) and Planch'Alizés, a disturbed site where coverage by Acropora was only $0.2 \%$ (Naïm, personal communication).

At each site, two kinds of branches of dead Acropora formosa were collected: branches which were grazed by the echinoid Echinometra mathaei and therefore without algal turf and fragments of Acropora covered with abundant algal turf in Stegastes nigricans territories. Living Acropora were also collected to act as controls.

\subsection{Sample preparations and analytical procedures}

Acropora species exhibit intra-colony variation in growth Gladfelter.1982: Oliver_1984 and to minimize this variation, only the tips of colonies were used for bioerosion study. These tips were approximately 12 to $15 \mathrm{~mm}$ long and 7 to $10 \mathrm{~mm}$ in diameter corresponding to a volume varying between 0.5 to $1.2 \mathrm{~cm}^{3}$. 


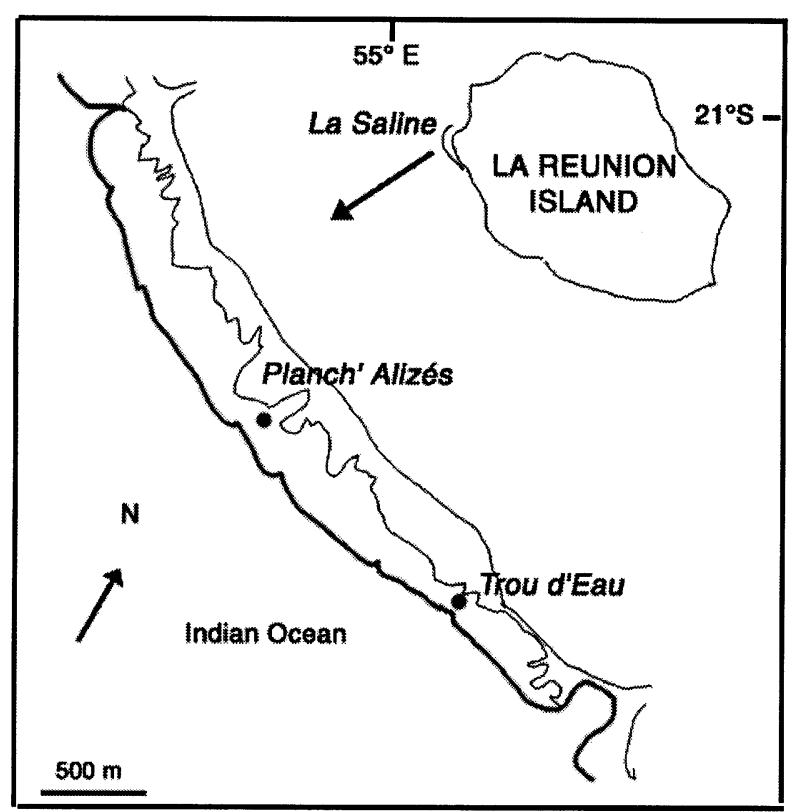

Figure 1. Location of the two sampling sites on La Saline reef.

The bulk density (i.e. the mass divided by the total enclosed volume) of living colonies of Acropora was measured from eight fragments collected near the tip of branches in the two sites. After removing all the living tissues with a sodium hypochlorite solution (13\%), their enclosed volume were measured by water displacement of the samples covered by a thin waterproof coating and they were then weighed at $60^{\circ} \mathrm{C}$.

Boring endoliths (microflora) were studied by fixing small chips of substrate in a buffered 2-3\% formaldehyde solution in sea water and dissolved with $5 \%$ solution of hydrochloric acid. The extracted endoliths were then mounted on slides and observed by light microscopy.

Two methods were used to estimate the bioerosion by microflora. Small surface chips of Acropora were cleaned of organic matter using a sodium hypochlorite solution and observed by scanning electron microscopy and computer-aided image analysis (Visilog). Photomicrographs (ten per samples) were used to calculate an integrated average percentage of the surface of substrate removed by microflora Le Campion-Alsumard et al 1995). The depth of penetration of the microflora was determined from skeletal fragments embedded in araldite, cut open and partially etched to expose resin casts of microborings, and observed by scanning electron microscopy (SEM) Le Campion-Alsumard et al. 1995) From these percentages of eroded surface and depth of penetration, the volume of $\mathrm{CaCO}_{3}$ extracted by microflora was estimated, and using the figures obtained for the bulk density, the bioerosion was calculated in grams of $\mathrm{CaCO}_{3}$ per cubic centimetre of dead coral substrate.

The boring meiofauna (diameter $<0.5 \mathrm{~mm}$ according to Kiene and Hutchings, 1994a and macrofauna (diameter $>0.5 \mathrm{~mm}$ ) were extracted from Acropora by dissolving branches with $18 \%$ hydrochloric acid after removal of epilithic algae and determination of their volume by water displacement. After substrate dissolution the boring species were separated from the cryptofauna. Estimates of bioerosion by fauna were made by determining the volume of all individuals extracted. It was not possible to measure meiofaunal bioerosion under SEM as per the microflora as their burrows were of similar size to the skeletal pores in Acropora.

A comparison of the boring flora and fauna biomass, allowed the relative importance of these two groups to be assessed. The resultant residue after acid dissolution was ranked and the boring flora and fauna identified, dried to constant mass at $60^{\circ} \mathrm{C}$ and weighed. Peyrot-Clausade et al_(1995) found this boring flora biomass underestimated in comparison with results obtained after samples were dried at $450^{\circ} \mathrm{C}$ for $5 \mathrm{~h}$ to remove organic matter, and therefore a correction factor of 1.5 was applied.

The univariate data display (box-plots) developed by Tukey Erigge et_al_ 1989 was used to illustrate the different results in the undisturbed and disturbed sites. Each sample is represented as a box, divided at the median, and 2 whiskers; the box length ends correspond to the first and last interquartile range and the whisker ends correspond to the first and the last decile. All the observations beyond these limits are plotted individually.

As the quantitative data obtained was in various units (percent, number of individuals per cubic centimetre, biomass in milligrams per cubic centimetre, etc...) different transformations (arc sinus for the percents, $\log (x+1)$ for the counts of individuals, $\log$ (for the biomass) are applied to obtain homogeneity of variance. The variance homogeneity was tested by Cochran test (Sachs, 1984).

Analysis of variance conducted were: a two-way Anova mixed nested model (model III) to define the optimism number of samples required, a series of 2-Anova fixed crossed model (model I) and a 3-fixed crossed model (model I) to compare principal factors effects and pos 
Table I. Two-way Anova on fauna borer biomass.

\begin{tabular}{lrlrl}
\hline Source of variation & $d f$ & MS & \multicolumn{1}{l}{$F$} & $p$ \\
\hline Coverage (A) & 1 & 0.8389 & 11.5287 & 0.029 \\
Branches (B < A) & 4 & 0.0728 & 2.1632 & 0.104 \\
Residual & 24 & 0.0336 & & \\
\hline
\end{tabular}

The mixed nested model was used to perform the analysis; the material was extracted from 15 fragments of 3 branches of dead Acropora for each of its 2 different coverage studied; $d f$ : degrees of freedom, $M S$ : Mean square, $F$ : F-test, $p$ : probability.

sible interactions. All analyses were performed with a 5\% significance (Zar, 1984) using the statistical packages Statview 5 (1998) and Super Anova 1.11 (1991). Mean values are given with standard deviations.

\section{RESULTS}

The biomass of boring fauna of five Acropora fragments of $0.5 \mathrm{~cm}^{3}$ volume from three branches from each treatment (grazed and protected area) were analysed using a 2-way Anova (nested model) (table- d). This indicated that the variability between fragments of the same branch is higher than the variability between the branches, so the fragments were taken at random in different branches from each sample. Five pieces of $0.5 \mathrm{~cm}^{3}$ from each coverage at each site were necessary to be representative of biomass of boring fauna of the dead coral branches.

The bulk density of living Acropora was not significantly different between the two sites, $(P=0.1755)$ table 1 - لd and the mean density estimated was $1.18 \pm 0.2 \mathrm{~g} \mathrm{~cm}^{-3}$. An analysis of the skeletal structure of living Acropora indicated that no microborers (figure 2) were present and that the mean size of pores was $99.46 \pm 21.56 \mu \mathrm{m}$.

\subsection{Boring microflora}

Three endolithic species penetrate through the coral skeletons from the surface. Resin-cast preparations cut

Table II. One-way Anova on bulk density of living Acropora collected in the undisturbed and disturbed sites.

\begin{tabular}{lrlll}
\hline Source of variation & $d f$ & MS & $F$ & $p$ \\
\hline Sites & 1 & 0.038 & 2.226 & 0.1530 \\
Residual & 18 & 0.017 & & \\
\hline
\end{tabular}

perpendicular to the surface of Acropora formosa revealed that the cyanobacteria Plectonema terebrans colonised the branch (up to $80 \%$ of the substrate) down to the central axis (figure 2); Mastigocoleus testarum was only present in the surface millimetre under the surface. The chlorophyte Ostreobium quekettii colonizes about $50 \%$ of the branch in all samples.

The percentage surface area removed by microflora from Acropora was significantly different between sites $(P=0.0001)$ and between grazed and ungrazed substrates $(P=0.025)$ (table III $)$. The substrate covered with algal turf was less bored than the heavily grazed one and Acropora at the disturbed site, were significantly more perforated than those from the undisturbed site. The mean percentage of surface eroded by microflora was $25.24 \pm 6.18$ (table I W . The box-plots (Goure indicate a higher variability on grazed substrates than on ungrazed substrates.

The mean depth of penetration (table I- varied from $0.483 \pm 0.196 \mathrm{~mm}$ in the substrate with algal turf at the disturbed site to $0.889 \pm 0.166$ in the grazed substrate on undisturbed site. Using these figures the amount of bioerosion was calculated for each site and for both grazed and ungrazed substrates and varied from $0.22 \pm 0.02 \mathrm{~g} \mathrm{~cm}^{-3}$ of $\mathrm{CaCO}_{3}(\mathrm{table} \mathrm{I-}$ ) in the algal turf covered Acropora at the undisturbed site to $0.38 \pm 0.04 \mathrm{~g} \mathrm{~cm}^{-3}$ of $\mathrm{CaCO}_{3}$ in Acropora subjected to grazing at the disturbed site. A 2-way analysis showed a significant difference between sites and between coverage of algae. Bioerosion by microflora was significantly lower at the undisturbed site than at the disturbed one, and also in substrates covered with algal turf when compared with grazed substrates (table $\mathrm{IW}$ ).

\subsection{Boring fauna}

The dominant groups found in the tips of Acropora were sipunculans and polychaetes. Molluscs and sponges were few and not considered in this study. The mean density of sipunculans varied from $1.02 \pm 0.88$ individuals $\mathrm{cm}^{-3}$ at the grazed Acropora of the disturbed site to $6.43 \pm 4.01$ individuals $\mathrm{cm}^{-3}$ in ungrazed substrates in the undisturbed site (table $\quad$ b). Polychaetes especially meiofaunal species, were more abundant than sipunculans with $91.70 \pm 26.20$ individuals $\mathrm{cm}^{-3}$ in the grazed substrate of the undisturbed site. The box-plots (figure 3 ) indicate that considerable variations in the density of 

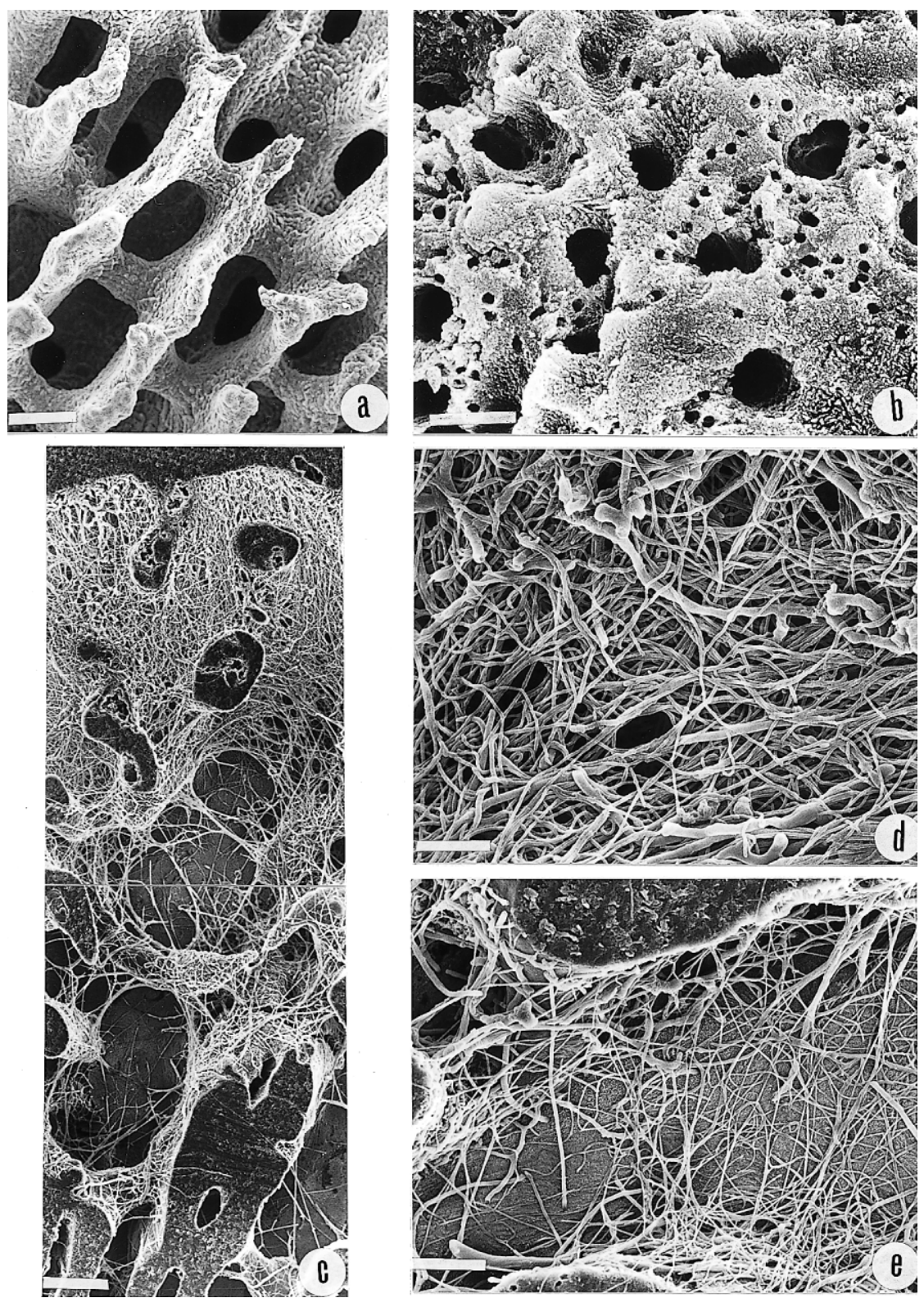

Figure 2. Scanning electron microscopy pictures of Acropora formosa after bleaching to remove organic matter: a. Structure of living Acropora formosa (scale bar $80 \mu \mathrm{m}$ ). b. Dead colonies of Acropora formosa surface: perforations made by Plectonema terebrans $(2 \mu \mathrm{m})$ and Mastigocoleus testarum $(5 \mu \mathrm{m})$ (scale bar $10 \mu \mathrm{m})$. Resin-cast boring tunnels of microborers. c. Transect from the surface to the centre of a cross section of an Acropora branch (scale bar $210 \mu \mathrm{m})$. d. Detail of the upper zone of transect showing a high density of tunnels (scale bar $40 \mu \mathrm{m}$ ). e. Detail of the median zone of the transect showing a low density of tunnels (scale bar $65 \mu \mathrm{m})$.

polychaetes and sipunculans occurred between sites and treatments. A 3-way anova (table V V d ) indicated a significant difference $(P=0.0001)$ in the density of sipunculans and polychaetes with a significant interaction occurring between coverage of substrate and borers (foure 4A). While high densities of sipunculans were found in dead Acropora covered with algal turf, polychaete densities were lower. Highest polychaete density was found in grazed substrates. A 3-way analysis performed on the densities of the abundant polychaete species, showed no interaction between the three factors $(P=0.1058)$ but a high interaction between coverage of substrate and polychaetes species $(P=0.0001)$. Substrates with large amounts of algal turf had high numbers of individuals of Polydora and Dodecaceria whereas the Sabellidae were more abundant in grazed substrates (figure $4 B$ ). The factors, sites and species also showed a significant interaction $(P=0.0393)$ : Polydora sp. and Dodecaceria 
Table III. Two-way Anova (fixed crossed model) on the percent of surface bored by microflora, the fauna and flora bioerosion and the flora and fauna biomass.

\begin{tabular}{|c|c|c|c|c|}
\hline & $d f$ & $M S$ & $F$ & $p$ \\
\hline \multicolumn{5}{|c|}{ Percent of surface bored by microflora } \\
\hline Site & 1 & 1240.55 & 139.54 & 0.0001 \\
\hline Coverage & 1 & 48.312 & 5.434 & 0.0255 \\
\hline Site* coverage & 1 & 3.77 & 0.424 & 0.5191 \\
\hline Residual & 36 & 8.891 & & \\
\hline \multicolumn{5}{|l|}{ Flora bioerosion } \\
\hline Site & 1 & 0.171 & 141 & 0.0001 \\
\hline Coverage & 1 & 0.007 & 5.647 & 0.0229 \\
\hline Site* coverage & 1 & 0.0004 & 0.374 & 0.5449 \\
\hline Residual & 36 & 0.001 & & \\
\hline \multicolumn{5}{|l|}{ Fauna bioerosion } \\
\hline Site & 1 & 0.001 & 3.915 & 0.0653 \\
\hline Coverage & 1 & 0.001 & 5.147 & 0.0375 \\
\hline Site*coverage & 1 & 0.001 & 3.566 & 0.0772 \\
\hline Residual & 16 & 0.0002 & & \\
\hline \multicolumn{5}{|l|}{ Flora biomass } \\
\hline Site & 1 & 1582.42 & 17.534 & 0.0007 \\
\hline Coverage & 1 & 51.713 & 0.573 & 0.4601 \\
\hline Site* coverage & 1 & 148.95 & 1.65 & 0.2172 \\
\hline Residual & 16 & 90.25 & & \\
\hline \multicolumn{5}{|l|}{ Fauna biomass } \\
\hline Site & 1 & 0.197 & 3.631 & 0.0749 \\
\hline Coverage & 1 & 0.262 & 4.832 & 0.0431 \\
\hline Site*coverage & 1 & 0.069 & 1.269 & 0.2766 \\
\hline Residual & 16 & 0.054 & & \\
\hline
\end{tabular}

Bioerosion values are in grams $\mathrm{CaCO}_{3}$ per cubic centimetre; biomass values are in milligrams per cubic centimetre.

sp. were more abundant at the polluted site, whereas Sabellidae were more abundant at the undisturbed site (Goure 4d).

Bioerosion by boring fauna varied from $0.05 \pm 0.02 \mathrm{~g} \mathrm{~cm}^{-3}$ of $\mathrm{CaCO}_{3}$ on grazed and ungrazed substrates at the disturbed site to $0.11 \pm 0.05 \mathrm{~g} \mathrm{~cm}^{-3}$ of
$\mathrm{CaCO}_{3}$ at ungrazed substrates at the undisturbed site. A 2-way anova (table II ) indicated that the amount of bioerosion was significantly different between grazed and ungrazed substrates $(P=0.03)$ but not between sites $(P=0.06)$. The box-plot indicated a large variability in the amount of bioerosion on ungrazed substrate at the undisturbed site (fgure 3 ).

Table IV. Characteristics and rates of microflora bioerosion.

\begin{tabular}{|c|c|c|c|c|}
\hline & \multicolumn{2}{|c|}{ Undisturbed site 'Trou d'Eau' } & \multicolumn{2}{|c|}{ Disturbed site 'Planch' Alizés' } \\
\hline & Grazed Acropora & Ungrazed Acropora & Grazed Acropora & Ungrazed Acropora \\
\hline Surface eroded by microflora $(\%)$ & $20.47 \pm 3.24$ & $18.88 \pm 1.78$ & $32.22 \pm 3.25$ & $29.41 \pm 2.40$ \\
\hline Mean depth penetration by microflora (mm) & $0.889 \pm 0.166$ & $0.676 \pm 0.088$ & $0.509 \pm 0.088$ & $0.483 \pm 0.196$ \\
\hline Internal microbioerosion $\left(\mathrm{g} \mathrm{CaCO}_{3} \mathrm{~cm}^{-3}\right)$ & $0.24 \pm 0.04$ & $0.22 \pm 0.02$ & $0.38 \pm 0.04$ & $0.34 \pm 0.03$ \\
\hline
\end{tabular}

Rates (mean $\pm \mathrm{SD}$ ) were calculated at the two sites and under varying levels of algal cover. 

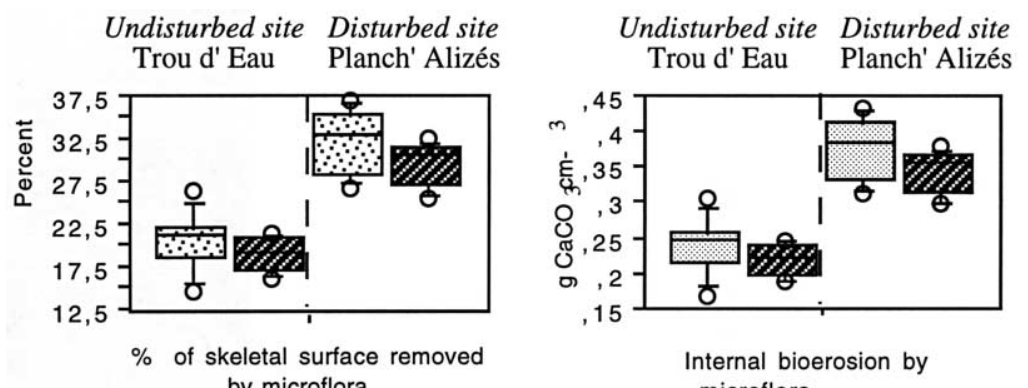

Internal bioerosion by by microflora
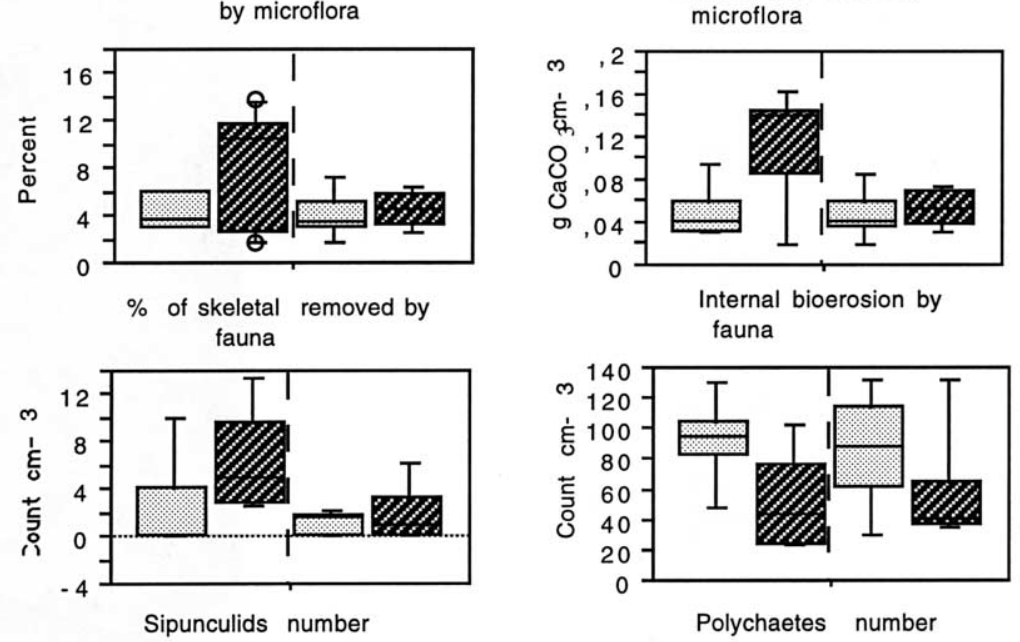

Figure 3. Box-plots of the calculated percentage of skeleton removed by boring flora and
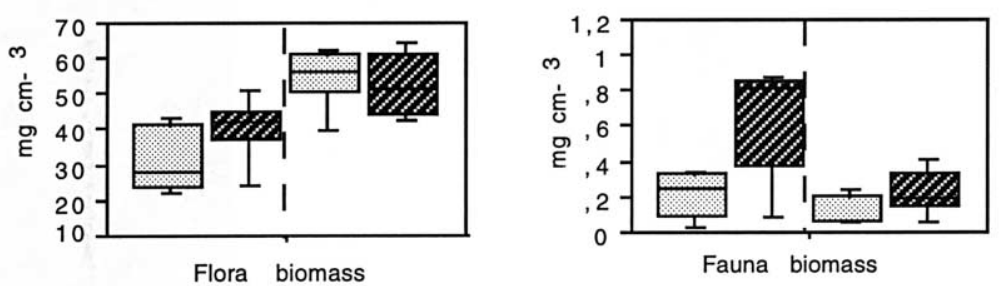
fauna, of the abundance of polychaetes and sipunculans and of the flora and fauna biomass in the two sites and under varying levels of algal cover.

Grazed dead Acropora

Dead Acropora covered by algal turf

\subsection{Boring flora and fauna biomass}

The biomass of microflora was not related to the amount of algal cover $(P=0.46)$ but differed significantly between sites $(P=0.0007)$. Levels ranged from $55.00 \pm 8.54 \mathrm{mg} \mathrm{cm}^{-3}$ at the disturbed site (table VId ) to $31.36 \pm 8.58 \mathrm{mg} \mathrm{cm}^{-3}$ at the undisturbed site. The boring fauna were significantly more abundant on ungrazed substrates regardless of site (figure 5). The maximum value of faunal biomass of $6.14 \pm 3.01 \mathrm{mg} \mathrm{cm}^{-3}$ was recorded on ungrazed substrate at the undisturbed site and this was largely due to high numbers of sipunculans.

\section{DISCUSSION}

The micro-boring species in dead Acropora formosa from Réunion were those found typically in all coral reef carbonate substrates Le Campion-Alsumard et al._1995). Plectonema terebrans, Mastigocoleus testarum and Ostreobium quekettii are the principal species of microflora. Living Acropora were devoid of microborers and especially the chlorophyte Ostreobium quekettii, which produces green bands in living Porites Le CampionAlsumard et al. 1995). Lukas (1973) also recorded an absence of green banding in the distal part of fast growing 
Table V. Abundance of macroborers (mean \pm SD) in dead Acropora bioerosion at the two sites and under varying levels of algal cover.

\begin{tabular}{|c|c|c|c|c|}
\hline & \multicolumn{2}{|c|}{ Undisturbed site 'Trou d'Eau' } & \multicolumn{2}{|c|}{ Disturbed site 'Planch' Alizés' } \\
\hline & High algal turf coverage & Grazed Acropora & High algal turf coverage & Grazed Acropora \\
\hline \multicolumn{5}{|l|}{ Sipunculans } \\
\hline Aspidosiphon sp. & $1.17 \pm 1.25$ & $0.80 \pm 1.60$ & $0.89 \pm 0.92$ & $0.22 \pm 0.44$ \\
\hline Phascolosoma sp. & $3.52 \pm 1.87$ & $0.80 \pm 1.60$ & $0.25 \pm 0.50$ & $0.79 \pm 0.66$ \\
\hline Apionsoma sp. & $1.75 \pm 1.35$ & 0 & 0 & 0 \\
\hline Juveniles & 0 & $0.72 \pm 0.99$ & $0.72 \pm 0.99$ & 0 \\
\hline Total & $6.43 \pm 4.01$ & $2.40 \pm 3.88$ & $1.86 \pm 2.34$ & $1.02 \pm 0.88$ \\
\hline \multicolumn{5}{|l|}{ Polychaetes } \\
\hline Sabellidae & $17.23 \pm 11.89$ & $77.0 \pm 34.70$ & $11.33 \pm 5.73$ & $48.21 \pm 28.84$ \\
\hline Polydora sp. & $32.23 \pm 22.19$ & $1.40 \pm 1.96$ & $35.83 \pm 38.32$ & $29.11 \pm 33.81$ \\
\hline Dodecaceria sp. & $1.50 \pm 1.86$ & $1.30 \pm 1.66$ & $3.05 \pm 2.46$ & $5.43 \pm 8.30$ \\
\hline Eunicidae & 0 & 0 & $1.61 \pm 2.20$ & 0 \\
\hline Spionidae & 0 & 0 & $0.44 \pm 0.54$ & 0 \\
\hline Cirratulidae & 0 & 0 & $4.72 \pm 3.65$ & 0 \\
\hline Juveniles & $1.00 \pm 2.00$ & $12.00 \pm 24.00$ & 0 & $0.51 \pm 0.63$ \\
\hline Total & $51.97 \pm 29.82$ & $91.70 \pm 26.20$ & $57.00 \pm 37.72$ & $85.92 \pm 34.42$ \\
\hline
\end{tabular}

corals such as Acropora cervicornis and A.palmata, although large branches and trunks from those corals had green bands.

The dominant families of sipunculans and polychaetes found in Réunion were also found in dead Porites in Australia (Hutchings et al. 1992) and in French Polynesia (Peyrot-Clausade et al., 1992)
The mean percentage bioerosion of microflora on the coral surface, $25.24 \pm 6.18 \%$, was similar to that recorded from Porites blocks after one year exposure on Réunion reefs (26.9\%) CChazottes. 1994. Microflora was distributed through the Acropora branch and had eroded about $0.29 \pm 0.07 \mathrm{~g} \mathrm{~cm}^{-3}$ of $\mathrm{CaCO}_{3}$ whereas in blocks of Porites, Chazottes (1994) recorded losses of

Table VI. Three-way Anova on the density of polychaetes and sipunculans.

\begin{tabular}{|c|c|c|c|c|}
\hline & $d f$ & $M S$ & $F$ & $p$ \\
\hline \multicolumn{5}{|l|}{ Polychaetes and sipunculans } \\
\hline Site & 1 & 0.233 & 2.395 & 0.1315 \\
\hline Coverage & 1 & 0.016 & 0.162 & 0.6897 \\
\hline Borers & 1 & 18.419 & 189.336 & 0.0001 \\
\hline Sites*Coverage & 1 & 0.046 & 0.473 & 0.4964 \\
\hline Sites*Borers & 1 & 0.128 & 1.316 & 0.2598 \\
\hline Coverage*Borers & 1 & 0.617 & 6.346 & 0.0171 \\
\hline Sites*Coverage*Borers & 1 & 0.226 & 2.324 & 0.1373 \\
\hline Residual & 32 & 0.097 & & \\
\hline \multicolumn{5}{|c|}{ Polydora, Dodecaceria and Sabellidae } \\
\hline Site & 1 & 0.531 & 4.267 & 0.0443 \\
\hline Coverage & 1 & 0.179 & 1.437 & 0.2365 \\
\hline Species & 2 & 4.886 & 39.236 & 0.0001 \\
\hline Sites*Coverage & 1 & 0.249 & 2.002 & 0.1635 \\
\hline Sites*Species & 2 & 0.431 & 3.464 & 0.0393 \\
\hline Coverage*Species & 2 & 1.731 & 13.761 & 0.0001 \\
\hline Sites*Coverage*Species & 2 & 0.293 & 2.354 & 0.1058 \\
\hline Residual & 48 & 0.125 & & \\
\hline
\end{tabular}

The density of polychaetes was analysed on three dominant species, using a fixed crossed model. 

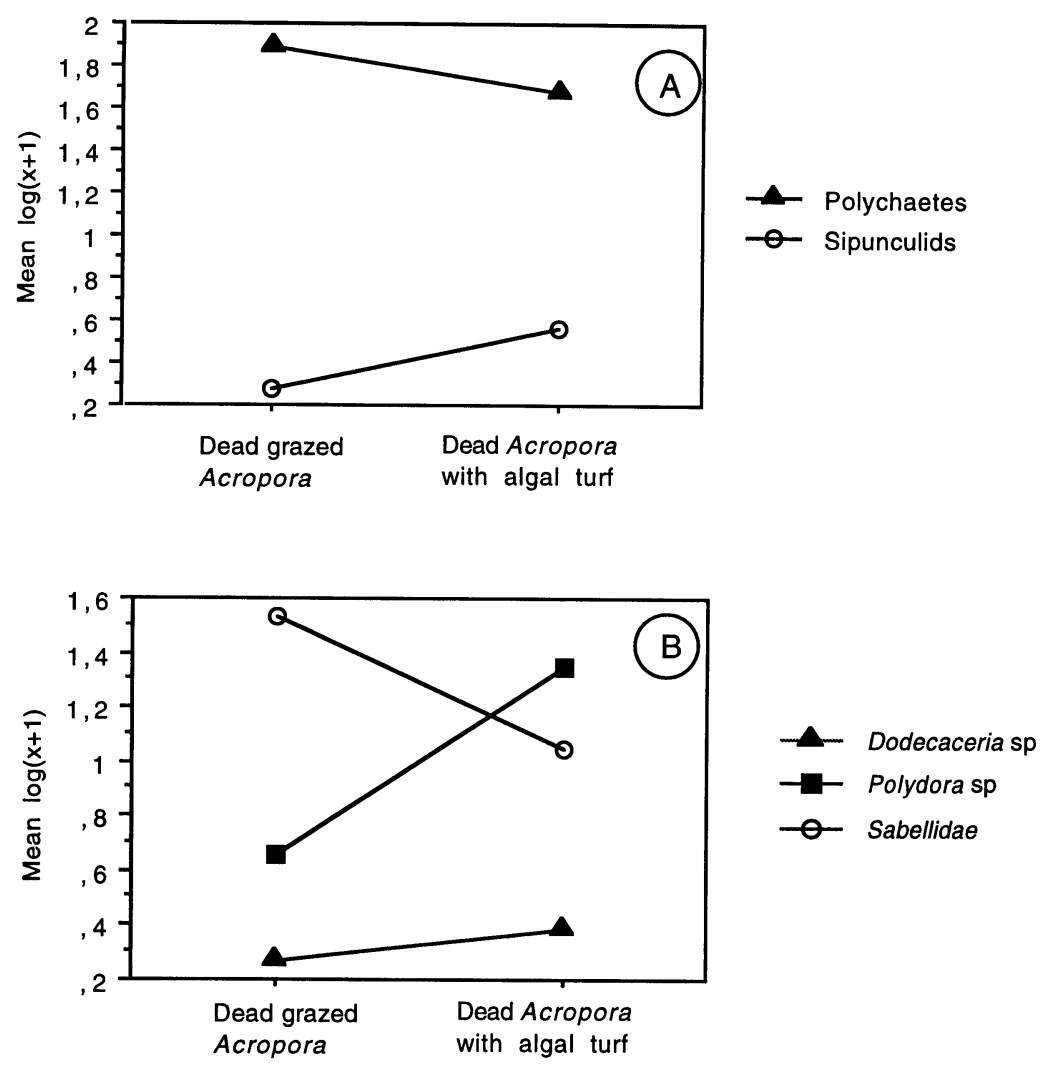

Figure 4. Interactions between coverage of dead Acropora and borer fauna (A), coverage and the principal polychaetes $(\mathbf{B})$, sites and the principal polychaetes $(\mathbf{C})$.
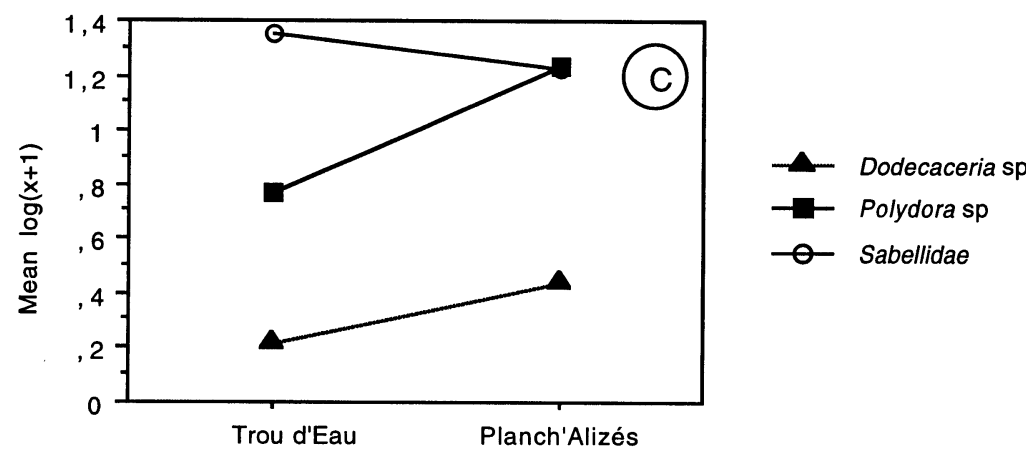

about $0.006 \mathrm{~g} \mathrm{~cm}^{-3}$ of $\mathrm{CaCO}_{3}$. The higher losses recorded for Acropora can be attributed to the large surface area available for recruitment compared to Porites. For example, in this study, $1 \mathrm{~cm}^{3}$ of Acropora has a surface area of 6 to $8 \mathrm{~cm}^{2}$ compared to $1 \mathrm{~cm}^{3}$ of Porites with only $1 \mathrm{~cm}^{2}$ of surface (Chazottes et al., 1995)

The mean density of all worms was higher than recorded from calcareous substrates studied Hutchings et al.
1992). The meiofaunal polychaetes were the most abundant group of borers with 72 individuals $\mathrm{cm}^{-3}$; in contrast Pari_et al (1998) recorded only 5 individuals $\mathrm{cm}^{-3}$ in Porites in French Polynesia. The mean density of sipunculans in this study was $6.4 \pm 4.0$ individuals $\mathrm{cm}^{-3}$, whereas only $1.1 \pm 0.5$ individuals $\mathrm{dm}^{-3}$ were reported from branched Acropora on Tulear reef, Madagascar Peyrot-Clausade and Brunel, 1990). Their rate of boring 
Table VII. Biomass of microflora and fauna at the two sites.

\begin{tabular}{llll}
\hline & Dead Acropora & Microflora biomass $\left(\mathrm{mg} \mathrm{cm}^{-3}\right)$ & Fauna biomass $\left(\mathrm{mg} \mathrm{cm}{ }^{-3}\right)$ \\
\hline Undisturbed site 'Trou d' Eau' & Grazed & $31.36 \pm 8.58$ & $2.07 \pm 1.24$ \\
& High algal turf coverage & $40.03 \pm 8.73$ & $6.14 \pm 3.01$ \\
Disturbed site 'Planch' Alizés' & Grazed & $55.00 \pm 8.54$ & $1.44 \pm 0.78$ \\
& High algal turf coverage & $52.36 \pm 8.55$ & $2.23 \pm 1.24$ \\
\hline
\end{tabular}

Values are mean \pm SD.

activity $\left(5.5 \%\right.$ of $\mathrm{CaCO}_{3}$ excavated) was similar to that found in Acropora cuneata at Lizard Island CMusso 1994)

\subsection{Impact of eutrophication on Acropora bioerosion}

Acropora collected at the disturbed site, Planch'Alizés, had more of the surface area bored by microflora $(30.81 \%$ of $\mathrm{CaCO}_{3}$ eroded) than at the undisturbed site $(19.68 \%)$. The biomass of the boring flora was also higher at the polluted site than at the undisturbed site, with large amounts of chasmolith (sensu algae). Similar results were recorded from Porites experimental blocks by Chazottes 1994) on Réunion reefs. Meanwhile, Kiene (1997) found that microbioerosion on ENCORE experiments on the

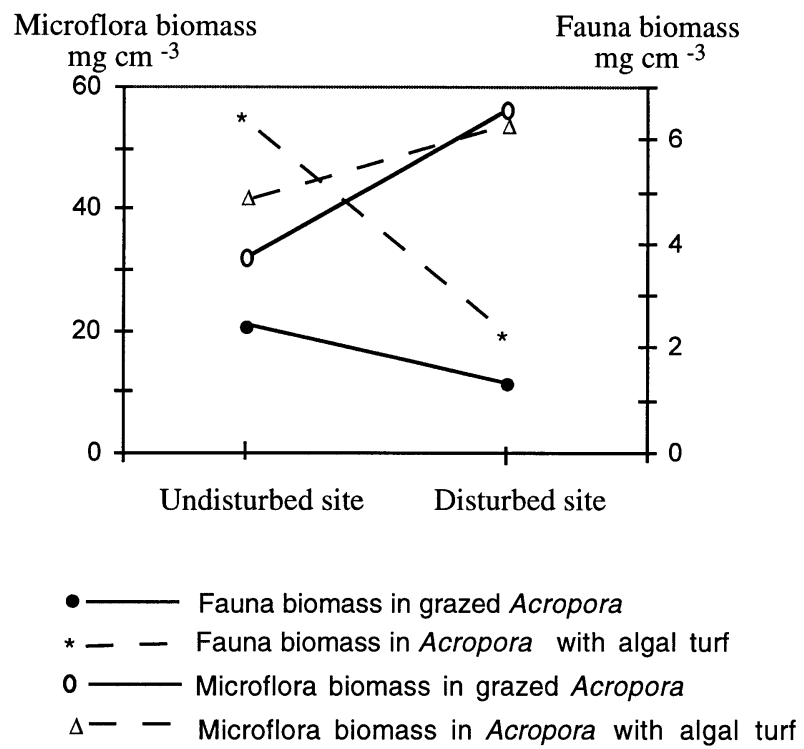

Figure 5. Graph of flora and fauna biomass according to coverage and sites.
Great Barrier Reef, was not influenced by the nutrient treatments. He explained this lack of response by microborers to the fact that sufficient nutrients were already available.

While no significant differences in the total number of boring species were recorded between sites, the suspension feeding Polydora spp. and deposit feeding Dodecaceria spp. which are characteristic of polluted sites (Davies and Hutchings. 1983: Lewis, 1998) were more abundant at Planch'Alizés. Similarly, boring sponges Cliona were more abundant at the disturbed site (Pari. 1998) with $60 \%$ of the Acropora branches infested whereas only $20 \%$ of branches were colonized at the undisturbed site. Holmes (1997) found that the mean proportion of Porites rubble invaded by clionids increased from the least eutrophic to the most eutrophic reefs.

\subsection{Impact of coverage of substrate on Acropora bioerosion}

The rates of microflora bioerosion were higher in grazed substrates $\left(0.36 \pm 0.04 \mathrm{~g} \mathrm{~cm}^{-3}\right.$ of $\left.\mathrm{CaCO}_{3}\right)$ than in ungrazed substrates, i.e. those samples collected in Stegastes territories and covered with algal turf $\left(0.28 \pm 0.02 \mathrm{~g} \mathrm{~cm}^{-3}\right.$ of $\left.\mathrm{CaCO}_{3}\right)$. Chazottes et al. (1995) suggested that the constant removal of substrate by grazers facilitates the deeper penetration of microborers into the substrate. In this study the mean depth penetration in grazed Acropora was $0.70 \mathrm{~mm}$, and only $0.58 \mathrm{~mm}$ in ungrazed substrates.

The meiofauna was also more abundant in the grazed substrates compared with ungrazed substrates. This conflicts with Hutchings (1986) who predicted that high grazing pressure would reduce larval recruitment, as the grazing would remove algal turf and newly settled faunal recruits. This study suggests that grazing may be benefi 
cial to larval recruitment by creating irregularities on the coral surface that facilitates settlement. Meiofaunal species may actively select Acropora substrate, as its natural high porosity allows them to penetrate easily. The macrofauna such as sipunculans were more abundant in Acropora covered with algal turf. Sipunculans are deposit feeders and may feed on small particles trapped in the algal turf, and this may provide protection from predators. Pari (1998) also recorded an increase in boring sponges in Acropora collected in damselfish territories. Sammarco et al. (1987). working on the Great Barrier Reef, also recorded higher rates of bioerosion by macroborers in damselfish territories compared to areas outside their territories.

In conclusion, the high rate of microbioerosion recorded for dead A. formosa as a result of a low ratio volume/ surface area and an high porosity of $61.95 \pm 2.14 \%$ Bucher et al_ 1998) would facilitate the rapid fragmentation of this coral in comparison to Porites, which has lower rates of microbioerosion and porosity of $36 \%$ Guillaume and Carrio-Schaffhauser, 1985. This high rate of microbioerosion will be increased by elevated nutrient levels in the water column, with the agents responsible for this loss varying according to whether the substrate is grazed or ungrazed.

\section{Acknowledgements}

We thank Pr. C. Conand and Écomar Laboratory (Université de La Réunion) for hosting us during the field work.

This study is a part of a long-term research on coral reefs bioerosion supported by the French National Program on Coral Reefs (PNRCO) and the French National Program on Coastal Environment (PNEC). We thank Dr T. Le Campion-Alsumard for her help on microborer studies, Dr J. Le Campion for his comments about statistical analysis and C. Bezac and C.Marshall for preparation of the SEM samples. We would like to thank Dr. P. Hutchings and Pr. C. Conand who have commented on the manuscript.

\section{REFERENCES}

Amor, A., Lopez Armengo, M.F., Rodriguez, A.M.I., Traversa, L.P., 1991. Intertidal endolithic fauna and its relationship to the mineralogical, physical and chemical characteristics of the substrate. Mar. Biol. 111, 271-280.

Bucher, D.J., Harriot, V.J., Roberts, L.G., 1998. Skeletal microdensity, porosity and bulk density of Acroporid corals. J. Exp. Mar. Biol. Ecol. 228, 117-136.
Chazottes, V., 1994. Étude expérimentale de la bioérosion et de la sédimentogénèse en milieu récifal; effets de l'eutrophisation (île de La Réunion, océan Indien occidental). Ph.D. thesis. Université Aix-Marseille 1, Marseille.

Chazottes, V., Le Campion-Alsumard, T., Peyrot-Clausade, M., 1995. Bioerosion rates on coral reefs: interactions between macroborers, microborers and grazers (Moorea, French Polynesia). Palaeogeogr., Palaeoclimatol., Palaeoecol. 113, 189-198.

Conand, C., Heeb, M., Peyrot-Clausade, M., Fontaine, M.F., 1998. Evaluations of bioerosion by two types of the sea urchin Echinometra mathaie o, several sites of a fringing reef in La Réunion (Indian Ocean) and comparison with other sites. In: Mooi, R., Telford, M. (Eds.), Echinoderms: San Francisco. A.A. Balkema, Rotterdam, pp. 609-615.

Cuet, P., Naïm O., Faure G., Conan J.Y., 1988. Nutrient-rich groundwater impact on benthic communities of La Saline fringing reef (Réunion): preliminary results. Proceedings of the 6th International Coral Reef Symposium, Panama, pp. 207-212.

Davies, P.J., Hutchings, P.A., 1983. Initial colonization, erosion and accretion on coral substrate: experimental results. Lizard Island Great Barrier Reef. Coral Reefs 2, 27-35.

Frigge, M., Hoaglin, D.C., Iglewicz, B., 1989. Some implementations of box-plot. Amer. Stat. 43, 50-54.

Gladfelter, E.H., 1982. Skeletal development in Acropora cervicornis.1. Patterns of calcium carbonate accretion in the axial corallite. Coral Reefs 1, 45-51.

Guillaume, M., Carrio-Schaffhauser, E., 1985. Non-influence of depth on porosity of Porites lutea skeleton in Réunion (West Indian Ocean). Proceedings of the 5th International Coral Reefs Congress, Tahiti, pp. 193-197.

Hallock, P., 1988. The role of nutrient availability in bioerosion: consequences to carbonate buildups. Palaeogeogr., Palaeoclimatol., Palaeoecol. 63, 275-291.

Highsmith, R.C., 1981. Coral bioerosion: damage relative to skeletal density. Amn. Nat. 117, 193-198.

Holmes, K.E., 1997. Eutrophication and its effect on bioeroding sponge communities. Proceedings of the 8th International Coral Reef Symposium, Panama, pp. 1411-1416.

Holmes, K.E., Edinger, E.N., Hariyadi, Limmon, G.V., Risk, M.J., 2000. Bioerosion of live massive corals and branching coral rubble on Indonesian coral reefs. Mar. Pol. Bull. 40, 606-617.

Hubbard, D.K., Miller, A.I., Scaturo, D., 1990. Production and cycling of calcium carbonate in a shelf-edge reef system (St Croix, U.S. Virgin Islands): application to the nature of reef systems in the fossil record. J. Sed. Petrol. 60, 335-360.

Hutchings, P., 1986. Biological destruction of coral reefs. A review. Coral Reefs 4, 239-252.

Hutchings, P., Kiene, W.E., Cunningham, R.B., Donnelly, C., 1992. Spatial and temporal patterns of non-colonial boring organisms (polychaetes, sipunculans and bivalva molluscs) in Porites at Lizard Island, Great Barrier Reef. Coral Reefs 11, 23-31.

Kiene W.E., 1997. Enriched nutrients and their impact on bioerosion: results from ENCORE. 8th International Coral Reef Symposium, Panama, pp. 897-902. 
Kiene, W.E., Hutchings, P.A., 1994a. Bioerosion experiments at Lizard Island, Great Barrier Reef. Coral Reefs 13, 91-98.

Kiene, W.E., Hutchings, P.A., 1994. Experimental investigations of patterns in the rates of bioerosion at Lizard island, Great Barrier Reef. Coral Reefs 13, 91-98.

Le Campion-Alsumard, T., Golubic, S., Hutchings, P., 1995. Microbial endoliths in skeleton of live and dead corals: Porites lobata (Mooréa, French Polynesia). Mar. Ecol. Prog. Ser. 117, 149-157.

Lewis, J.B., 1998. Reproduction, larval development and functional relationships of the burrowing, spionid polychaete Dipolydora armata with the calcareous hydrozoan Millepora complanata. Mar. Biol. 130, 651-662.

Lukas, K.J., 1973. Taxonomy and ecology of the endolithic microflora of reef coral with a review of the literature on endolithic microphytes. Ph.D. thesis. University of Rhode Island, Providence.

Musso, B.M., 1994. Internal bioerosion of in situ living and dead corals on the Great Barrier Reef. James Cook University of North Queensland, Townsville.

Oliver, J.K., 1984. Intra-colony variation in the growth of Acropora formosa: extension rates and skeletal structure of white (Zooxanthellae-free) and brown-tipped branches. Coral Reefs 3, 139-147.

Pari, N., 1998. Les éponges perforantes dans les milieux récifaux actuels et anciens: signification écologiques et paléoécologiques. Université d'Aix-Marseille I, Marseille.

Pari, N., Peyrot-Clausade, M., Le Campion-Alsumard, T., Hutchings, P., Chazottes, V., Golubic, S., Le Campion, J., Fontaine, M.F., 1998.
Bioerosion of experimental substrates on high islands and on atoll lagoons (French Polynesia) after two years of exposure. Mar. Ecol. Prog. Ser. 166, 119-130.

Peyrot-Clausade, M., Brunel, J.F., 1990. Distribution patterns of macroboring organisms on Tuléar reef flats (SW Madagascar. Mar. Ecol. Prog. Ser. 61, 133-144.

Peyrot-Clausade, M., Chazottes, V., Pari, N., 1999. Bioerosion in the carbonate budget of two Indo-Pacific reefs: La Réunion (Indian Ocean) and Moorea (Pacific Ocean. Bull. Geol. Soc. Denmark 45, 151-155.

Peyrot-Clausade, M., Hutchings, P.A., Richard, G., 1992. Temporal variations of macroborers in massive Porites lobata on Moorea, French Polynesia. Coral Reefs 11, 161-166.

Peyrot-Clausade, M., Le Campion-Alsumard, T., Hutchings, P., Payri, C., Fontaine, M.F., 1995. Initial bioerosion and bioaccretion on experimental substrates in high island and atoll lagoons (French Polynesia. Oceanol. Acta 18, 531-541.

Risk, M.J., Sammarco, P.W., Edinger, E.N., 1995. Bioerosion in Acropora across the continental shelf of the Great Barrier Reef. Coral reefs 14, 79-86.

Sachs, L., 1984. Applied statistics. A handbook of techniques. PUBLISHER ? Heidelberg.

Sammarco, P.W., Risk, M.J., Rose, C., 1987. Effects of grazing and damselfish territoriality on internal bioerosion of dead corals: indirect effects. J. Exp. Mar. Biol. Ecol. 112, 185-199.

Statview, 1998. User's manual. Statview, Berkeley, CA.

Super Anova 1.11, 1991. User's manual. Berkeley, CA.

Zar, J.H., 1984. Biostatistical analysis, 2nd edition. Prentice-Hall, Englewood Cliffs, NJ. 